АРХИПСКИЙ А. О., ЛИНЧЕВСКИЙ И. В.

\title{
АВТОГЕНЕРАТОР НА МАГНИТООПТИЧЕСКОМ КРИСТАЛЛЕ
}

\author{
Национальный технический университет Украинь \\ «Киевский политехнический институт», \\ Украина, Киев, 03056, пр-т Победь 37
}

\begin{abstract}
Аннотация. Рассмотрены физические принципы построения автогенератора с оптическим каналом в цепи обратной связи на основе магнитооптического кристалла, совершающего магнитомеханические колебания. Приведена схема автогенератора с использованием кристалла иттриевого феррит граната, а также результаты его экспериментального исследования
\end{abstract}

Ключевые слова: генератор, магнитооптический кристалл, магнитомеханический резонанс, generator, magneto-optical crystal, magnetomechanical resonance

\section{ВВЕДЕНИЕ}

В технике широкое распространение нашли автогенераторы, в которых стабилизация частоты колебаний производится с помощью кварцевых резонаторов. Изменение частоты таких генераторов практически невозможно, т.к. частота автоколебаний определяется частотой высокодобротных механических колебаний резонатора. С другой стороны известно, что ферримагнетики (ФМ) при помещении в постоянное поляризующее магнитное поле (МП) изменяют свой модуль Юнга до 10-15\% [1]. Таким образом, в ФМ существует, возможность управления скоростью распространения ультразвуковых волн путем изменения величины и ориентации поляризующего материал МП.

Это свойство ФМ предлагается использовать для построения магнитоуправляемого автогенератора на базе магнитооптического кристалла (МОК). В работах $[2,3]$ проведены исследования по резонансному изменению индуктивности катушки оригинальной конструкции с тороидальным сердечником, который может совершать радиальные механические колебания. Однако, в силу особенностей МП в тороидальном сердечнике, управление жесткостью сердечника и соответственно частотой автогенератора внешним МП затруднено.

Целью работы является рассмотрение физических принципов построения, нахождение условий выполнения баланса фаз и амплитуд для магнитоуправляемого автогенератора на МОК в режиме магнитомеханического резонанса. Также экспериментально подтверждена возможность управления частотой автогенератора за счет изменения постоянного МП.

\section{1. ВЛИЯНИЕ МАГНИТОМЕХАНИЧЕСКИХ КОЛЕБАНИЙ МОК НА ПОЛЯРИЗАЦИЮ СВЕТОВОЙ ВОЛНЫ}

Рассмотрим МОК, который имеет форму длинного стержня длиной $2 l$, т.е. его поперечные размеры будем считать значительно меньшими его длины. Для создания магнитомеханических колебаний МОК помещают внутрь соленоида, МП которого направлено вдоль оси стержня $0 x_{2}$ и содержит постоянную $H_{0}$ и переменную $h(t)$ составляющие.

Поле $H_{0}$ является поляризующим, его значение выбирают из соображений обеспечения максимальной чувствительности намагничен- 